OPEN ACCESS

Edited by:

Eleonore Fröhlich,

University of Tübingen, Austria

Reviewed by:

Marina Evans,

United States Environmental

Protection Agency, USA

Dharmendra Kumar Yadav,

All India Institute of Medical Sciences,

India

${ }^{*}$ Correspondence:

Marzena Jamrógiewicz

majam@gumed.edu.pl

Specialty section:

This article was submitted to

Predictive Toxicology,

a section of the journal

Frontiers in Pharmacology

Received: 22 December 2015

Accepted: 19 April 2016

Published: 04 May 2016

Citation:

PikulP, Jamrógiewicz M,

Nowakowska J, Hewelt-BelkaW

and Ciura K (2016) Forced

Degradation Studies of Ivabradine and In Silico Toxicology Predictions

for Its New Designated Impurities.

Front. Pharmacol. 7:117.

doi: 10.3389/fphar.2016.00117

\section{Forced Degradation Studies of Ivabradine and In Silico Toxicology Predictions for Its New Designated Impurities}

\author{
Piotr Pikul ${ }^{1}$, Marzena Jamrógiewicz ${ }^{1 *}$, Joanna Nowakowska', Weronika Hewelt-Belka ${ }^{2,3}$ \\ and Krzesimir Ciura ${ }^{1}$
}

1 Department of Physical Chemistry, Faculty of Pharmacy with the Subfaculty of Laboratory Medicine, Medical University of Gdańsk, Gdańsk, Poland, ${ }^{2}$ Department of Analytical Chemistry, Chemical Faculty, Gdańsk University of Technology, Gdańsk, Poland, ${ }^{3}$ Mass Spectrometry and Chromatography Laboratory, Pomeranian Science and Technology Park, Gdynia, Poland

All activities should aim to eliminate genotoxic impurities and/or protect the API against degradation. There is a necessity to monitor impurities from all classification groups, hence ivabradine forced degradation studies were performed. Ivabradine was proved to be quite durable active substance, but still new and with insufficient stability data. Increased temperature, acid, base, oxidation reagents and light were found to cause its degradation. Degradation products were determined with the usage of HPLC equipped with Q-TOF-MS detector. Calculations of pharmacological and toxicological properties were performed for six identified degradation products. Target prediction algorithm was applied on the basis of Hyperpolarization-activated cyclic nucleotide-gated cation channels, as well as more general parameters like logP and aqueous solubility. Ames test and five cytochromes activities were calculated for toxicity assessment for selected degradation products. Pharmacological activity of photodegradation product (UV4), which is known as active metabolite, was qualified and identified. Two other degradation compounds ( $\mathbf{O x} \mathbf{1}$ and $\mathbf{N} \mathbf{1}$ ), which were formed during degradation process, were found to be pharmacologically active.

Keywords: ivabradine, stress testing, stability, LC-MS/MS, in silico, ADME/Tox calculations

\section{INTRODUCTION}

Guidelines for assessing the quality of active pharmaceutical ingredient (API) and medicinal products has been developed by ICH, FDA, WHO or EMA, which are focused to the greatest extent, firstly to verify the stability of the API through the establishment of various tests and the way there are conducted (ICH Q1A, 1993). Secondly, the confirmation of the presence of impurities is performed (ICH Q3A, 1993). Studies are performed to explore various paths of the potential degradation of the API, evaluating the rate of changes under the influence of various factors.

For a comprehensive evaluation process associated with the pharmaceutical stability, there is a need to perform various tests, which results should be the answer whether the drug substance is stable. The most important for the drug substance are so-called stress tests, which involve overly intense exposure to factors such as: strong acid, base, hydrogen peroxide, high temperature or light, 
A<smiles>CNCCCN1CCc2cc(OC)c(OC)cc2CC1=O</smiles>

B<smiles>COc1cc2c(cc1OC)C(C=O)C2</smiles>

C<smiles>COc1cc2c(cc1OC)CN(CCCNCC1Cc3cc(OC)c(OC)cc3CC1=O)CC2</smiles>

D<smiles>COc1cc2c(cc1OC)CC(=O)N(CCC=O)CC2</smiles>

$\mathbf{F}$
E<smiles>CNCCCN1CCc2cc(OC)c(OC)cc2CC1=O</smiles><smiles>COc1cc2c(cc1OC)CN(CCC[N+](C)([O-])CC1Cc3cc(OC)c(OC)cc3CC1=O)CC2</smiles>

FIGURE 1 | Theoretical metabolites: main (rank 1) - (A-C) and secondary (rank 3 and $>4$ ) - (D-F) generated by the usage of software Toxtree.

in a manner individual to the different drugs (ICH Q1A (R2), 2003; Waterman and Adami, 2005). When the chemical stability of APIs is considered, the effects of chemical reactions of the API are evaluated, mainly: hydrolysis in conditions of increased humidity, oxidation in the presence of oxygen or hydrogen peroxide, isomerization, hydration, dimerization, or decarboxylation. Photostability tests are characterized by particular specificity and are an integral part of stability tests that are included in standard, ICH Q1A (1993). It is worth noting that the concept of photodegradation is related not only to changes in the structure of the API under the influence of light, but also to the occurrence of free-radical processes, energy transfer, or even luminescence, which may lead to unexpected and atypical results, especially in the solid state (Glass et al., 2004). There is a special need to recognize all possibilities of degradation of new pharmaceutical compound especially those, which are not recognized in Pharmacopeia yet.

Determination of unknown impurities in the new drug compound is based on the results obtained during various stress tests, thus during chemical stability evaluation. Identification of degradation products is primarily concentrated on establishing its structure, with simultaneous determination of physicochemical properties, and then toxicity estimation accordingly to the latest recommendations (Carstensen and Rhodes, 2000; EMEA, 2004; Olsen and Larew, 2005; Huynh-Ba, 2008). The first ICH regulations regarding the quantitation limit of impurities in drug, were based solely on a patient daily dose of API, routes of administration and duration of therapy and the identification of impurity of concentration below $0.1 \%$ was unrequired (ICH Q3B (R), 2000). In addition, there was also the lack of awareness of impurities existing in the drug substance itself, but in the finished product mainly. In 2004 there has been a noticeable change in the approach to standards and thresholds of impurities, as a reaction to the proposal developed by the EMEA, in which necessity for determination of the genotoxic impurities limits in the API was stated (EMEA, 2004; Modi et al., 2012). It has been proposed that the lowest possible quantitation limit of impurities should be enforced in cases of the predicted presence of a genotoxic substance formed from an API (Dow et al., 2013; Maggio et al., 2013). The latest guidelines has been developed in 2014 and requirement to use at least two forecasting models of mutagenicity predicting in silico was established.

According to current recommendations, it is important to provide a lot of results in the area of stability testing research in case of newly implemented pharmaceutical compounds as well as others already known (Jamrógiewicz, 2016). Ivabradine 


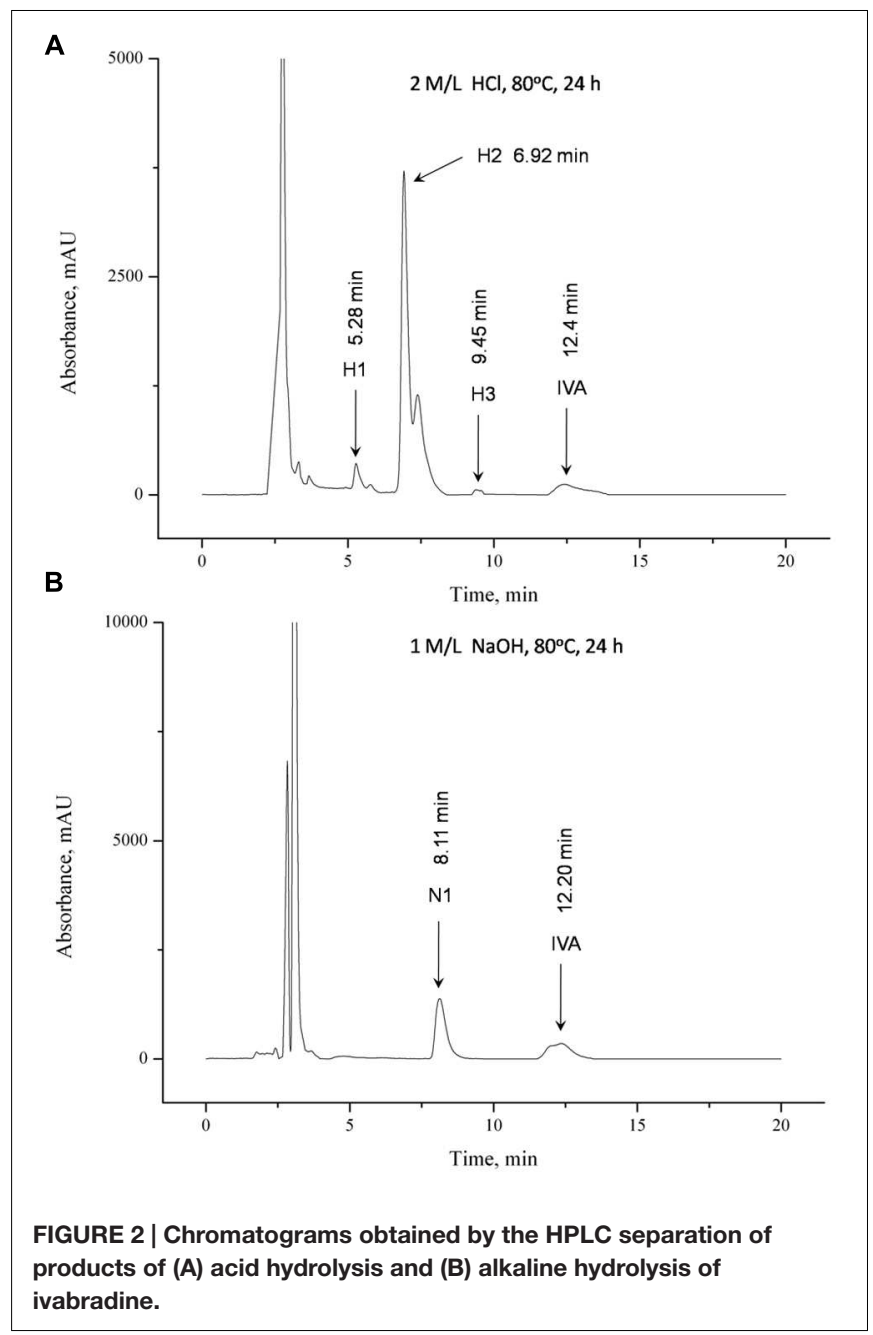

(IVA) is a new drug compound in the treatment of heart failure patients and the only implemented HCN4 channel inhibitor. The drug received an expedited review under the FDA's priority review program and the approval was based on results of the shift trial, published in 2010. Locking HCN4 channel results in slower growth of pacemaker current and as a result reducing the heart rate. Such action is used to treat angina, especially in patients with intolerance to $\beta$-blockers. IVA is metabolized by cytochrome CYP3A4 and does not affect metabolism and plasma concentration of other cytochome inhibitors. Ivabradine is a highly soluble $S$-enantiomer with no in vivo conversion. The only known active metabolite is $N$-desmethyl ivabradine (DiFrancesco, 2010; EMA, 2015). There are no officially published impurities for IVA in pharamacopeias. The only results focused on degradation and in silico studies have been performed recently (Patel et al., 2015). So that, it is important to provide an independent point of view and new data.

There are many models and approaches of in silico studies (Singh et al., 2012, 2013). In this work, Prediction Swiss Target and ePhysChem tools were applied (Gfeller et al., 2014; ePhysChem, 2015). By using the above-mentioned software, we evaluated the toxicity of some identified degradation products. They

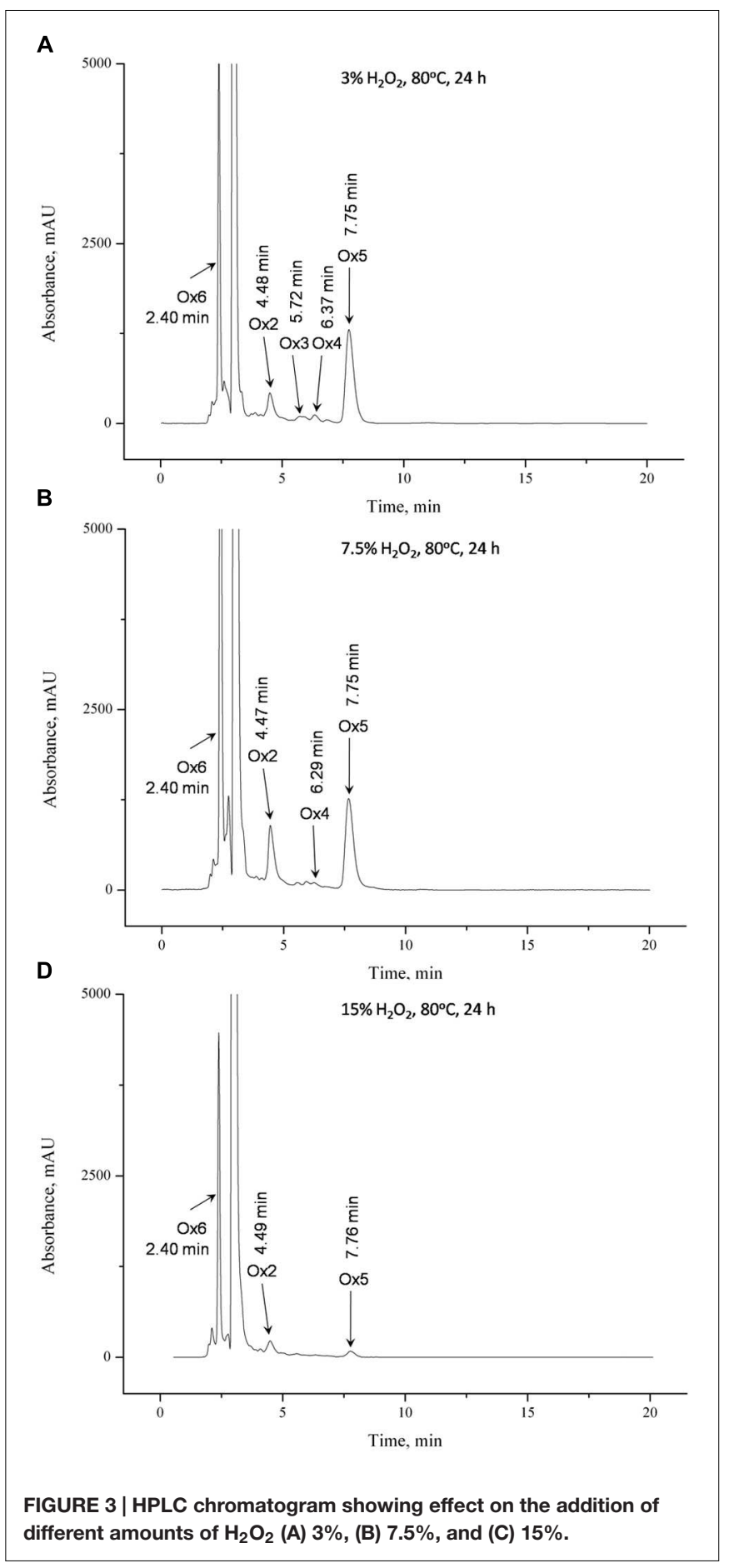

were defined by physicochemical parameters such as $\log \mathrm{P}$ and solubility, which determine the pharmacokinetics. The IVA impact on cytochrome P450 (a group of enzymes with oxidase activity responsible among other things for the detoxification of the body) has also been examined (Danielson, 2002). The major enzyme from the group of cytochrome P450 isoenzymes is CYP3A4, responsible for the metabolism of most drugs or xenobiotics. Drugs can be metabolized by different enzymes 


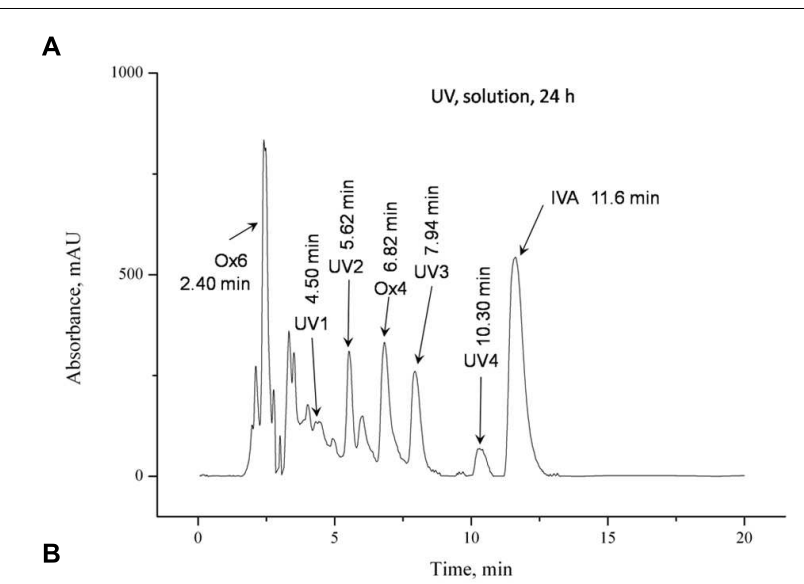

B
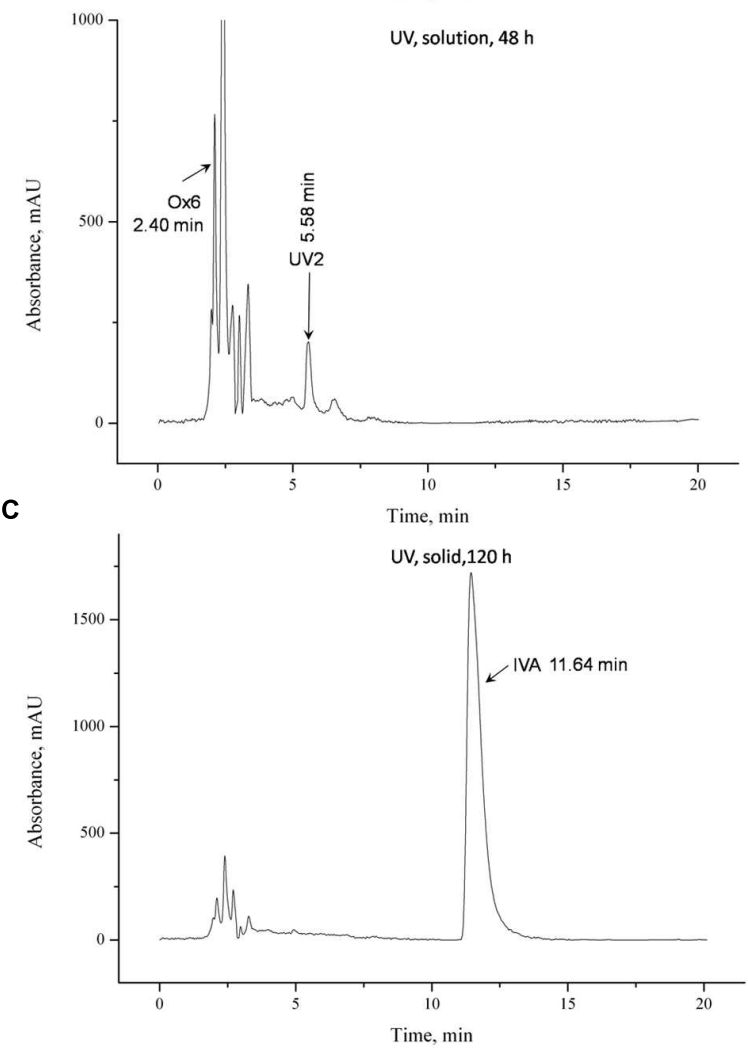

FIGURE 4 | HPLC chromatogram showing photolytic degradation in solution (A) for $24 \mathrm{~h},(B) \mathbf{4 8}$, and (C) in solid for $120 \mathrm{~h}$.

such as CYP2D6, CYP2C9, CYP2C19, and CYP1A2, therefore, different metabolites are formed, which activity may be similar to the original drug substance. Sometimes these products cause toxic effects (Zanger and Schwab, 2013; Patel et al., 2015).

Physicochemical parameters such as $\log \mathrm{P}$ and solubility of degradation products are discussed in this work because of their importance in perspective of pharmacokinetics (Alavijeh et al., 2005; Bergström, 2005). If the drug is administered orally, as ivabradine, it is exposed to low $\mathrm{pH}$ in the stomach, which may form chlorides drug substance with altered properties (Bergström, 2005).
The main object of this work is to conduct a forced degradation of ivabradine and propose its possible degradation products. Stress tests were carried out mainly in context of resistance to the oxidizing agent, light as well as acid and base hydrolysis. Additionally, the calculated physicochemical, pharmacological and toxic properties of possible degradation products were presented.

\section{MATERIALS AND METHODS}

\section{Chemicals}

The tested ivabradine hydrochloride (purity $\geq 99 \%$ ) bulk powder was supplied by Watson International Ltd. (Kunshan, China). Acetonitrile was purchased from Sigma-Aldrich Chemical CO. (St. Louis, MO, USA), ammonium acetate, hydrochloric acid and sodium hydroxide all pure p. a. were purchased from POCH (Gliwice, Poland). 30\% Hydrogen peroxide was supplied by J. T. Baker, (Deventer, The Netherlands). Pure water was obtained from Direct-Q3 UV-R Ultrapure water purification system, Merck Millipore (Darmstadt, Germany).

\section{Equipment and Conditions}

LC-MS/MS analysis was performed with HPLC Agilent 1100 (AgilentTechnologies, Santa Clara, CA, USA) equipment coupled with QSTAR XL (AbSciex, Framingham, MA, USA) mass spectrometer. Electrospray ionization (ESI) was operated in a positive ion mode in order to obtain soft and efficient ionization of ivabradine and its degradation products. Kromasil $100 \mathrm{C} 8(4.6 \mathrm{~mm} \times 250 \mathrm{~mm}, 5 \mu \mathrm{m}$, AkzoNobel, Amsterdam, Netherlands) was used in reversed-phase mode with isocratic elution. Mobile phase composition was $65 \%$ of component A (20 mM ammonium acetate) and $35 \%$ of component B (acetonitrile). Total analysis time was $30 \mathrm{~min}$. Column temperature throughout the analysis was $25^{\circ} \mathrm{C}$ the flow rate of the mobile phase was $1 \mathrm{ml} / \mathrm{min}$ and the injection volume was $20 \mu \mathrm{l}$. The high resolution Q-TOF mass spectrometer was operated in SCAN mode to obtain mass spectrum in the mass range $220-1000 \mathrm{~m} / \mathrm{z}$. MS/MS mass spectra were obtained by collision-induced dissociation of selected parent ions in Product Ion mode of mass spectrometer. Degradation studies were carried out in Thermostat CC2-K6 made by Huber company (Offenburg, Germany), photo stability studies were performed in a photostability Suntest + Atlas chamber (Accelerated Tabletop

TABLE 1 | Degradation products of all tested samples.

\begin{tabular}{|c|c|c|}
\hline Sample & Degradation products & Ivabradine [min] \\
\hline Acid decomposition & $\mathrm{H1}, \mathrm{H} 2, \mathrm{H} 3$ & 12.40 \\
\hline Alkaline decomposition & $\mathrm{N} 1$ & 12.20 \\
\hline Oxidation $\left(3 \% \mathrm{H}_{2} \mathrm{O}_{2}\right)$ & $O \times 1, O \times 2, O \times 3, O \times 4, O \times 5$ & - \\
\hline Oxidation $\left(7.5 \% \mathrm{H}_{2} \mathrm{O}_{2}\right)$ & $\mathrm{O} \times 1, \mathrm{O} \times 2, \mathrm{O} \times 4, \mathrm{O} \times 5$ & - \\
\hline Oxidation $\left(15 \% \mathrm{H}_{2} \mathrm{O}_{2}\right)$ & Ox1, Ox2, Ox5 & - \\
\hline Photolysis (24 h) & Ox1, UV, UV2, Ox4, UV3, UV4, & 11.60 \\
\hline Photolysis (48 h) & Ox1, UV2 & - \\
\hline Photolysis (powder 120 h) & - & 11.64 \\
\hline
\end{tabular}




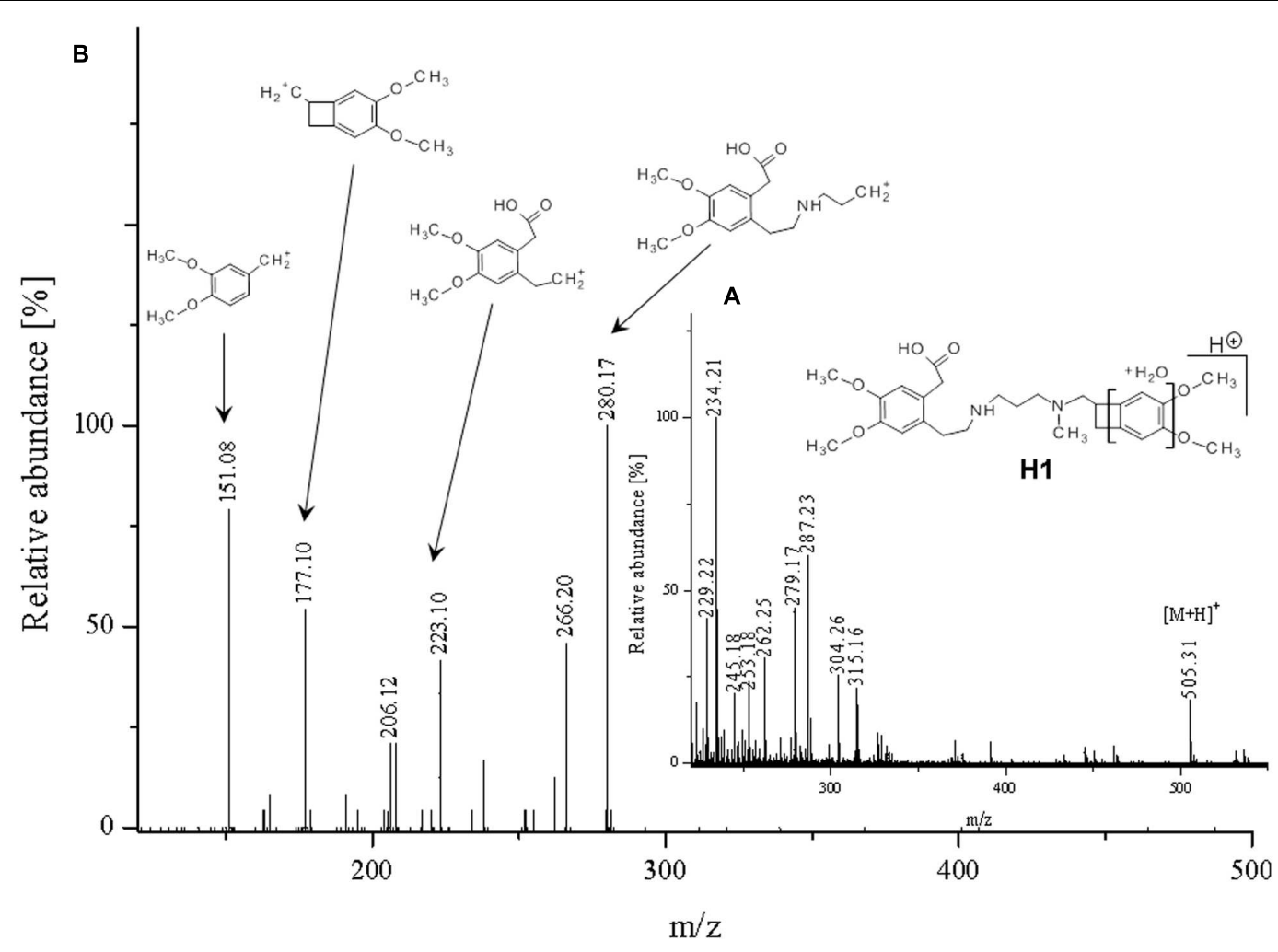

FIGURE 5 | Proposed structure and MS/MS fragmentation pattern of H1. (A) MS spectrum and (B) MS/MS spectrum of $[\mathrm{M}+\mathrm{H}]^{+}$ion at $505.31 \mathrm{~m} / \mathrm{z}$.

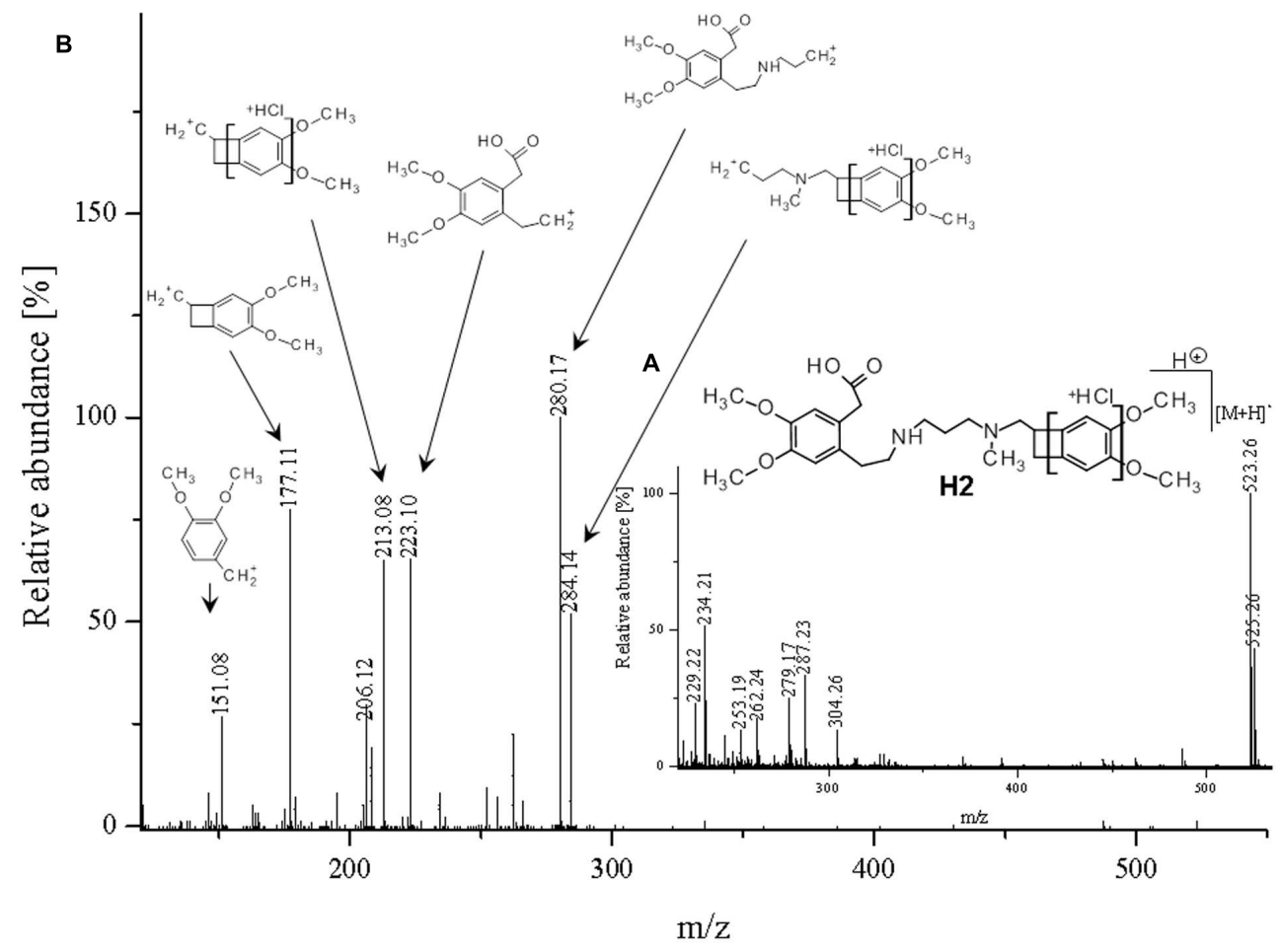

FIGURE 6 | Proposed structure and MS/MS fragmentation pattern of H2. (A) MS spectrum and (B) MS/MS spectrum of $[\mathrm{M}+\mathrm{H}]^{+}$ion at $523.26 \mathrm{~m} / \mathrm{z}$. 


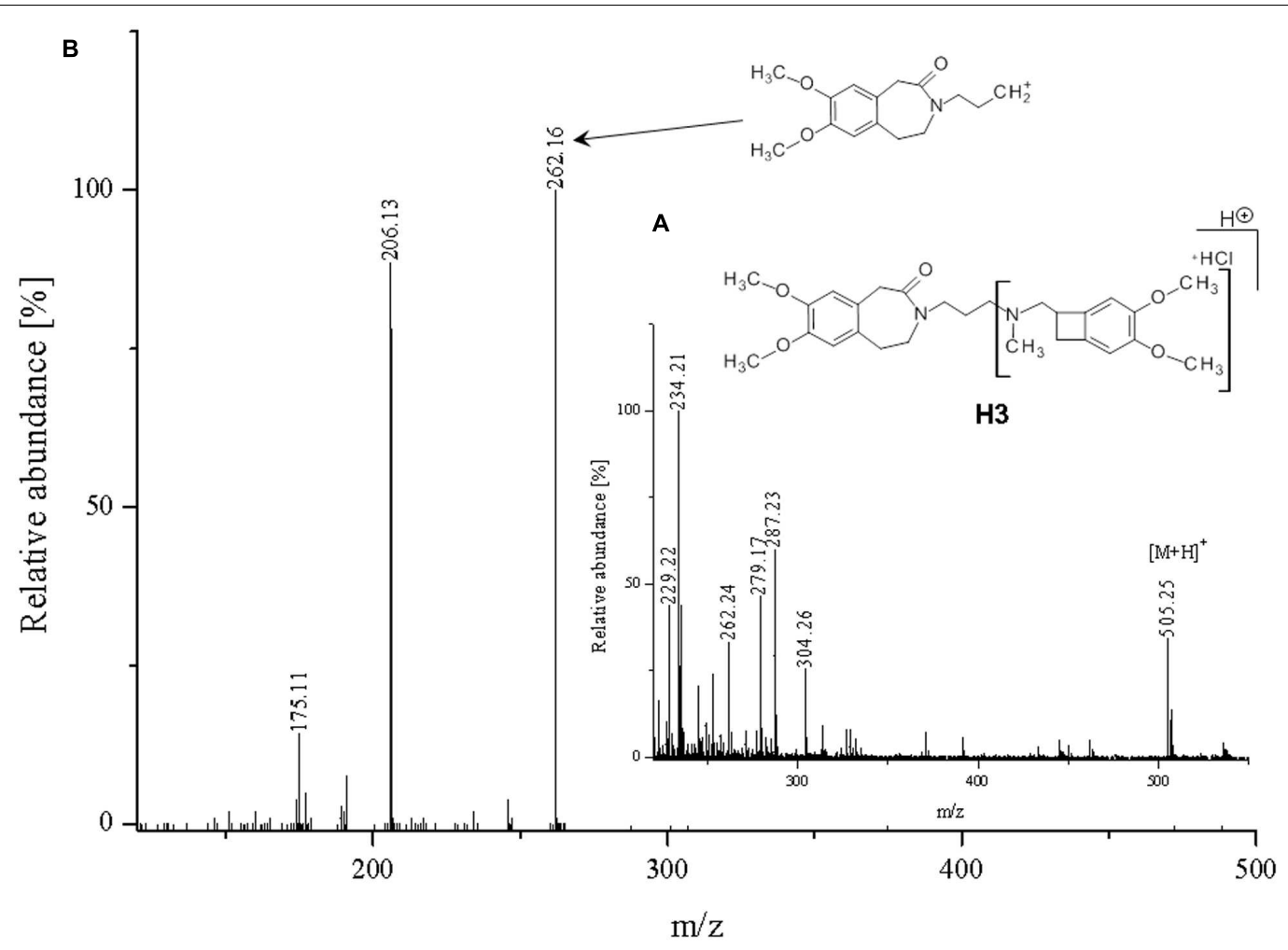

FIGURE 7 | Proposed structure and MS/MS fragmentation pattern of H3. (A) MS spectrum and (B) MS/MS spectrum of $[\mathrm{M}+\mathrm{H}]^{+}$ion at $505.25 \mathrm{~m} / \mathrm{z}$.

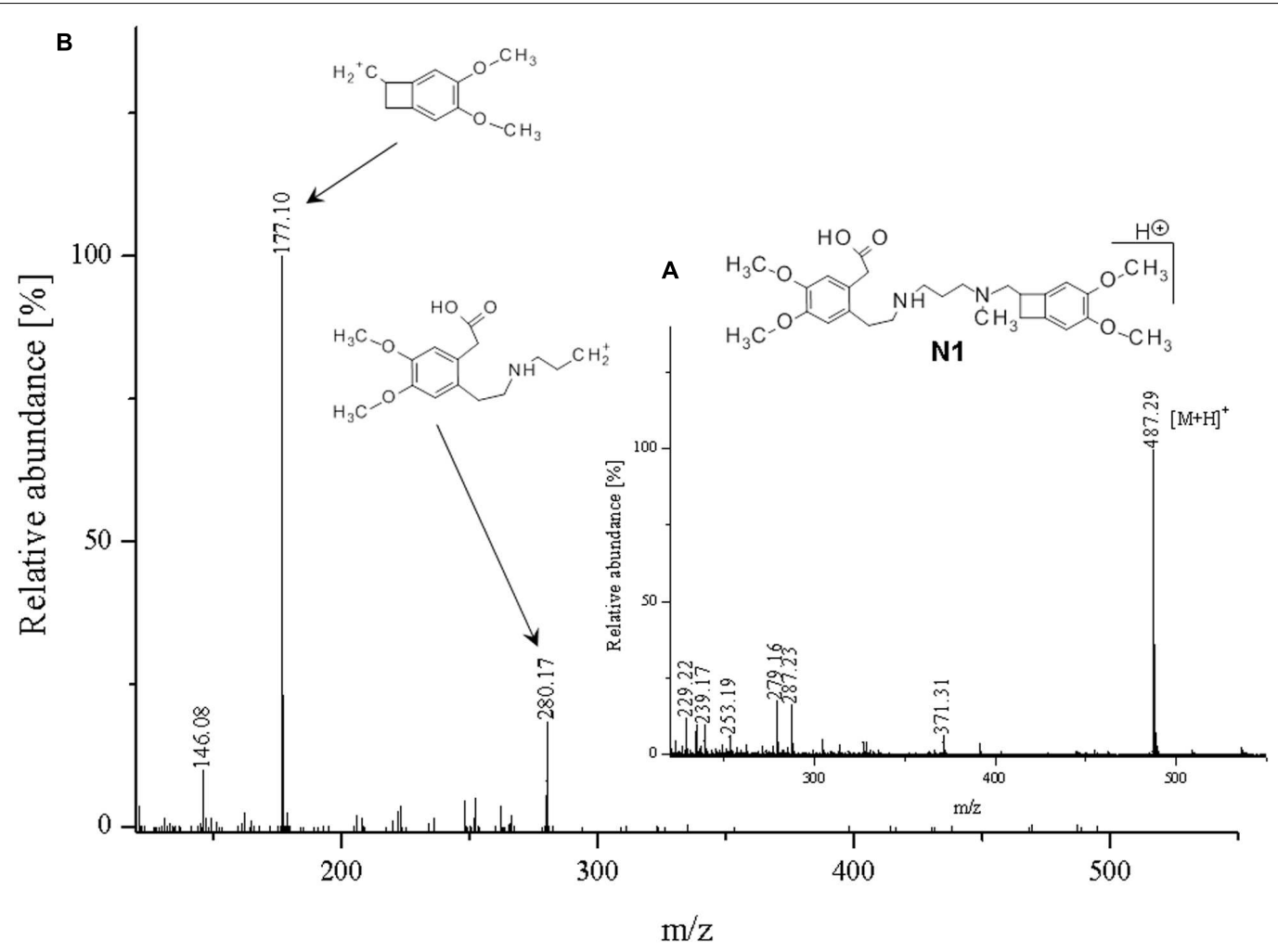

FIGURE 8 | Proposed structure and MS/MS fragmentation pattern of N1. (A) MS spectrum and (B) MS/MS spectrum of $[\mathrm{M}+\mathrm{H}]^{+}$ion at $487.29 \mathrm{~m} / \mathrm{z}$. 


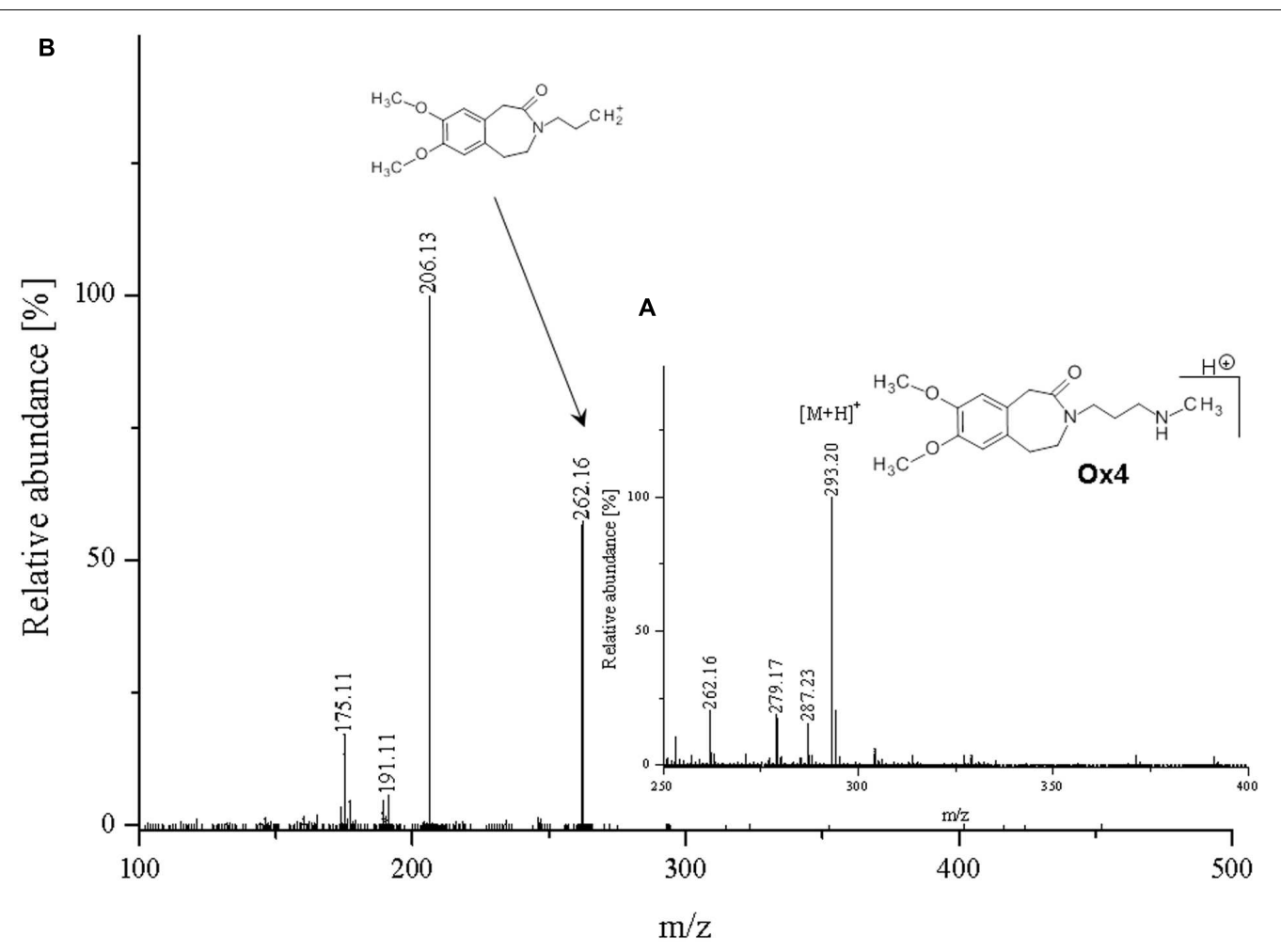

FIGURE 9 | Proposed structure and MS/MS fragmentation pattern of Ox4. (A) MS spectrum and (B) MS/MS spectrum of $[\mathrm{M}+\mathrm{H}]^{+}$ion at $293.20 \mathrm{~m} / \mathrm{z}$.

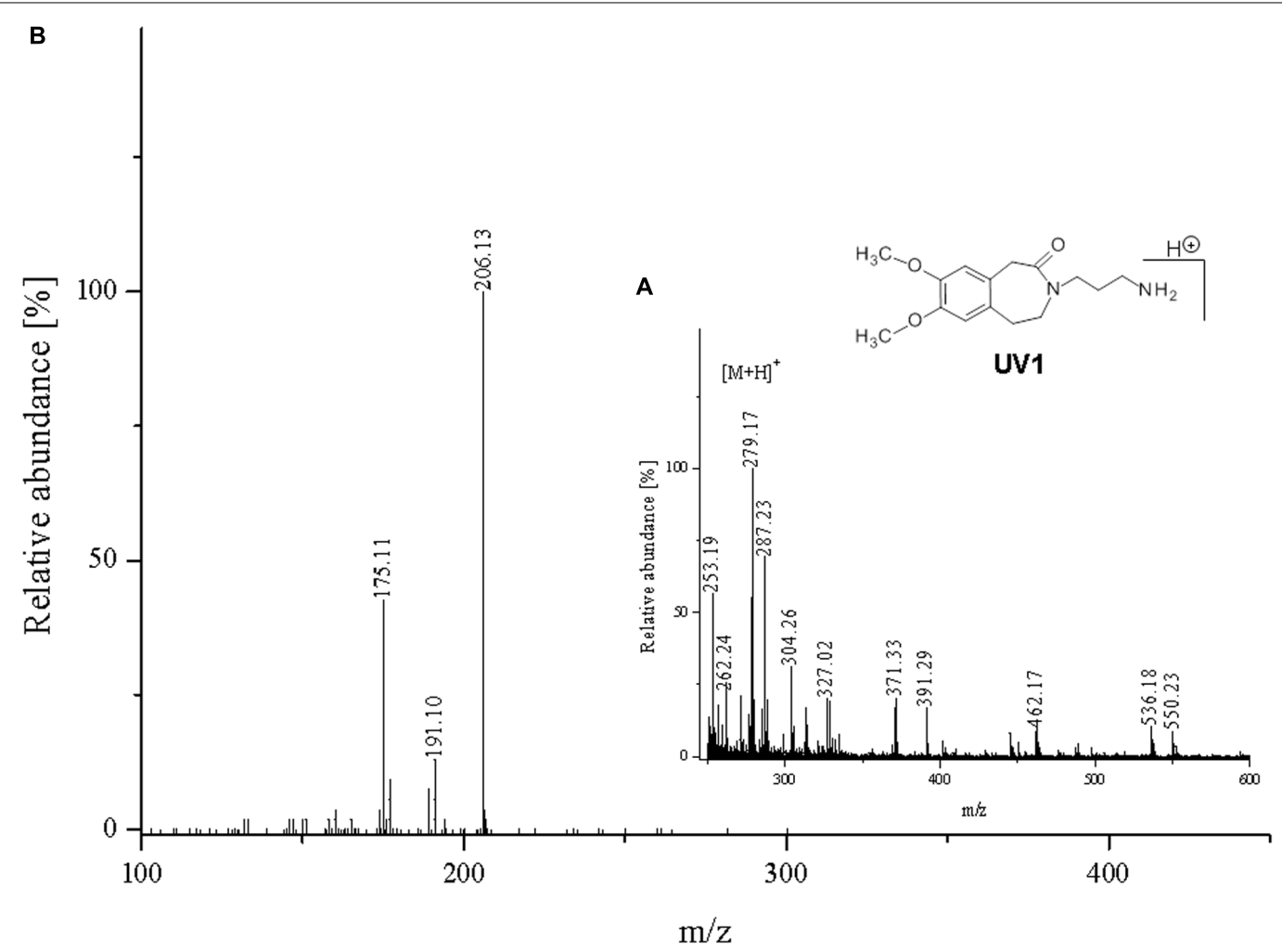

FIGURE 10 | Proposed structure and MS/MS fragmentation pattern of UV1. (A) MS spectrum and (B) MS/MS spectrum of $[\mathrm{M}+\mathrm{H}]^{+}$ion at $279.17 \mathrm{~m} / \mathrm{z}$. 


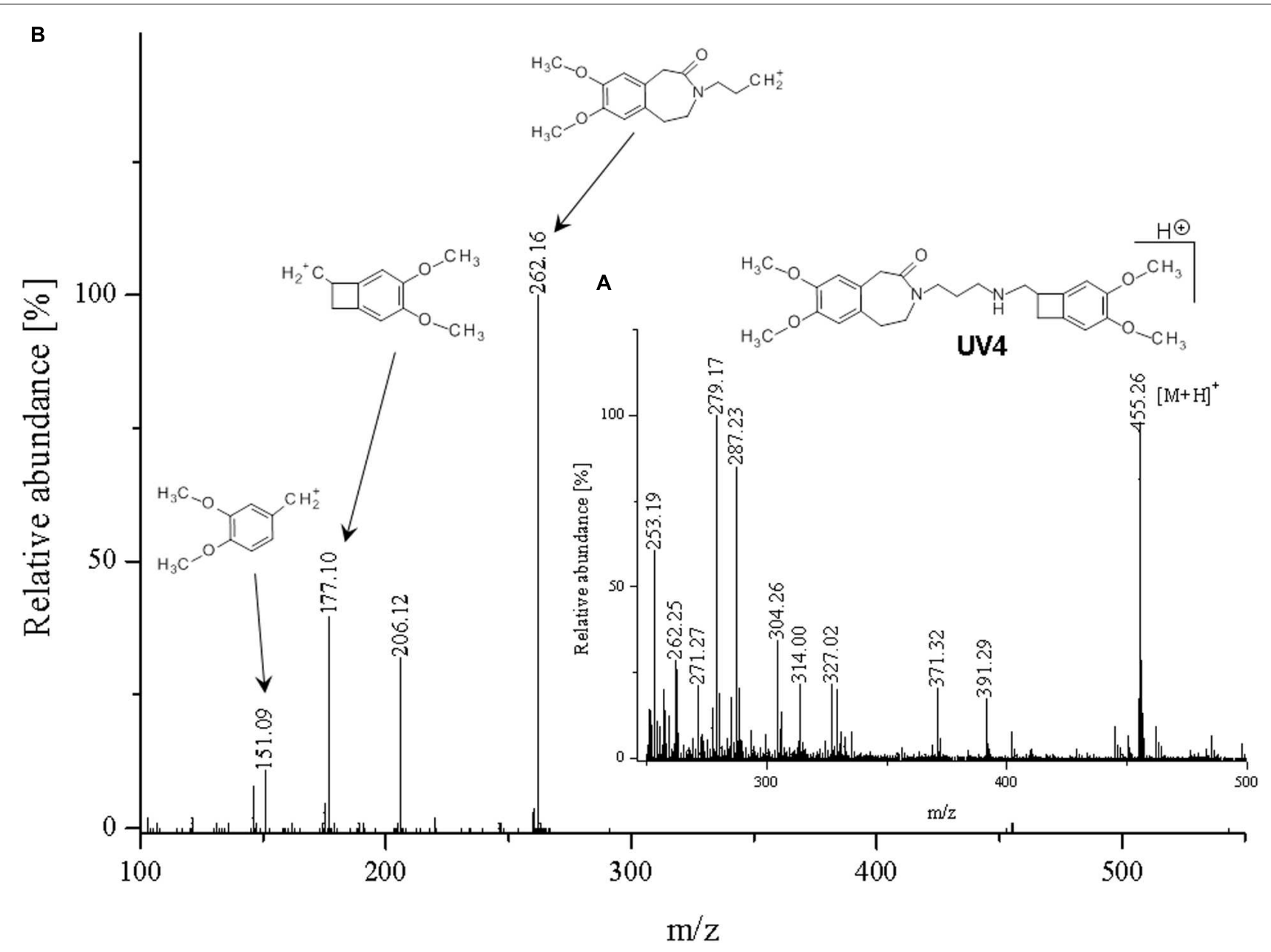

FIGURE 11 | Proposed structure and MS/MS fragmentation pattern of UV4. (A) MS spectrum and (B) MS/MS spectrum of $[\mathrm{M}+\mathrm{H}]^{+}$ion at $455.26 \mathrm{~m} / \mathrm{z}$.

Exposure Systems) with xenon lamp. Shimadzu UV-1800 UV-Vis spectrophotometer was also used in the studies.

\section{Stress Testing}

In order to prepare degradation sample, for each of the samples $1 \mathrm{mg}$ of ivabradine were weighed and dissolved in $2 \mathrm{ml}$ of the appropriate solvent for particular test sample.

Thermal degradation was performed by adding deionized water and kept for $24 \mathrm{~h}$ in $80^{\circ} \mathrm{C}$. To achieve an acid and alkaline hydrolysis a $2 \mathrm{M} \mathrm{HCl}$ solution and $1 \mathrm{M} \mathrm{NaOH}$ were added, respectively, respectively and incubated for $24 \mathrm{~h}$ in $80^{\circ} \mathrm{C}$. Studies of possible oxidation products were carried out by adding 3\% $\mathrm{H}_{2} \mathrm{O}_{2}, 7.5 \% \mathrm{H}_{2} \mathrm{O}_{2}$ and $15 \% \mathrm{H}_{2} \mathrm{O}_{2}$ and incubated for $24 \mathrm{~h}$ in $80^{\circ} \mathrm{C}$. Photolytic degradation was performed in solution of deionized water for 24 and $48 \mathrm{~h}$ as well as in solid form for $120 \mathrm{~h}$. The illuminance was set at $500 \mathrm{~W} / \mathrm{m}^{2}$.

\section{In Silico Calculations}

Ivabradine is metabolized by cytochrome P450. To calculate the probable metabolites, Toxtree program was used (Toxtree, 2015), applying SMARTCyp method to predict the fragments in the molecule, which are the most susceptible to activity of cytochrome P450.

For the calculation of toxicity (CYP3A4, CYP2D6, CYP2C9, CYP2C19, and CYP1A2), logP, solubility and Ames test, ePhysChem (2015) was used, while the prediction of degradation compounds on potassium/sodium hyper polarization activated cyclic nucleotide-gated channel 4 ( $\mathrm{HCN} 4)$ were counted using SwissTargetPrediction (Gfeller et al., 2014). Calculations were made for IVA and compounds N1, Ox1, Ox4, Ox5, UV1, and UV2.

\section{RESULTS AND DISCUSSION}

\section{Metabolism/Degradation Products Prediction}

Cytochrome $\mathrm{P} 450$ is an enzyme, which demonstrates a monooxygenase activity (Zanger and Schwab, 2013). In the absence of these enzymes, but with an appropriate amount of supplied energy as heat, redox potential, a strong electrolyte, or UV radiation, reactions can occur in vitro 
TABLE 2 | Comparison of structural formulas, chemical formulas, retention times, molecular ions, as well as the fragment ions of the products obtained in the experiment.

\begin{tabular}{|c|c|c|c|c|c|}
\hline No & $\begin{array}{l}\text { Structural } \\
\text { formula }\end{array}$ & Chemical formula & $\begin{array}{l}\text { Retention time } \\
{[\text { [min] }}\end{array}$ & {$[\mathrm{M}+\mathrm{H}]^{+}$} & Fragment ions $^{\mathrm{a}}$ \\
\hline \multicolumn{6}{|c|}{ Hydrolysis } \\
\hline $\mathrm{H} 1$ & & $\mathrm{C}_{27} \mathrm{H}_{40} \mathrm{ClN}_{2} \mathrm{O}_{7}$ & $\mathrm{HCl}-5.28$ & 505 & $\begin{array}{l}151,177,206 \\
223,266,280\end{array}$ \\
\hline H3 & & $\mathrm{C}_{27} \mathrm{H}_{37} \mathrm{ClN}_{2} \mathrm{O}_{5}$ & $\mathrm{HCl}-9.45$ & 505 & 206, 262 \\
\hline N1 & & $\mathrm{C}_{27} \mathrm{H}_{38} \mathrm{~N}_{2} \mathrm{O}_{6}$ & $\mathrm{NaOH}-8.11$ & 487 & 177,280 \\
\hline $0 \times 2$ & Unknown & $\begin{array}{c}3 \% \mathrm{H}_{2} \mathrm{O}_{2}-4.48 \\
7.5 \% \mathrm{H}_{2} \mathrm{O}_{2}-4.47 \\
15 \% \mathrm{H}_{2} \mathrm{O}_{2}-4.49\end{array}$ & Inconclusive & & \\
\hline Ox3 & & $\mathrm{C}_{27} \mathrm{H}_{34} \mathrm{~N}_{2} \mathrm{O}_{6}$ & $3 \% \mathrm{H}_{2} \mathrm{O}_{2}-5.72$ & 471 & $177,192,206,248$ \\
\hline Ox4 & & $\mathrm{C}_{16} \mathrm{H}_{24} \mathrm{~N}_{2} \mathrm{O}_{3}$ & $\begin{array}{c}3 \% \mathrm{H}_{2} \mathrm{O}_{2}-6.37 \\
7.5 \% \mathrm{H}_{2} \mathrm{O}_{2}-6.29 \\
\text { UV } 24 \mathrm{~h}-6.82\end{array}$ & 293 & 175, 206, 262 \\
\hline$x \cup V 1$ & & $\mathrm{C}_{15} \mathrm{H}_{22} \mathrm{~N}_{2} \mathrm{O}_{3}$ & UV $24 h-4.5$ & 279 & 175, 191, 206 \\
\hline UV2 & & $\mathrm{C}_{16} \mathrm{H}_{24} \mathrm{~N}_{2} \mathrm{O}_{4}$ & $\begin{array}{c}\text { UV } 24 h-5.56 \text { UV } \\
48 h-5.58\end{array}$ & 309 & $204,260,278$ \\
\hline UV3 & & $\mathrm{C}_{27} \mathrm{H}_{36} \mathrm{~N}_{2} \mathrm{O}_{6}$ & UV $24 \mathrm{~h}-7.94$ & 485 & $146,177,204,278$ \\
\hline UV4 & & $\mathrm{C}_{26} \mathrm{H}_{34} \mathrm{~N}_{2} \mathrm{O}_{5}$ & UV $24 \mathrm{~h}-11.6$ & 455 & $151,177,206,262$ \\
\hline
\end{tabular}

to form the same or similar degradation products. Using the structure of the molecule and the Toxtree software (Toxtree, 2015), theoretical metabolites which may be produced by the action of cytochrome P450 were calculated (Figure 1).

These theoretical degradation products formed by the $N$-demethylation (Figures 1A-E) and $N$-oxidation (Figure 1F) are presented in Figure 1.

\section{Chromatogram Evaluation}

Ivabradine was tested with the addition of $\mathrm{HCl}$ and $\mathrm{NaOH}$ (Figures 2A,B), wherein the concentration of used $\mathrm{HCl}$ was greater than the concentration of used $\mathrm{NaOH}$. On the chromatogram obtained from a sample after acidic hydrolysis reaction of IVA (Figure 2A) a satisfactory separation of ivabradine and the degradation products is observed. Only compound $\mathbf{H} 2$ was not separated from other neighboring 
TABLE 3 | Measured and calculated mass of molecular ion and fragmentation ion of degradation products, with calculated mass error.

\begin{tabular}{|c|c|c|c|}
\hline Monoisotopic mass & Measured & Theoretical & Mass error in $\mathrm{m} / \mathrm{z}$ \\
\hline \multirow[t]{3}{*}{ IVA $[\mathrm{M}+\mathrm{H}]^{+}$} & 469.2775 & 469.2697 & -0.0078 \\
\hline & 262.1509 & 262.1438 & -0.0071 \\
\hline & 177.1053 & 177.0910 & -0.0143 \\
\hline \multirow[t]{5}{*}{$\mathrm{H} 1[\mathrm{M}+\mathrm{H}]^{+}$} & 505.2908 & 505.3073 & 0.0165 \\
\hline & 280.1543 & 280.1684 & 0.0141 \\
\hline & 223.0965 & 223.1020 & 0.0055 \\
\hline & 177.0901 & 177.1003 & 0.0102 \\
\hline & 151.0754 & 151.0814 & 0.0060 \\
\hline \multirow[t]{7}{*}{$\mathrm{H} 2[\mathrm{M}+\mathrm{H}]^{+}$} & 523.2590 & 523.2569 & 0.0021 \\
\hline & 284.1424 & 284.1412 & 0.0012 \\
\hline & 280.1684 & 280.1543 & 0.0141 \\
\hline & 223.1020 & 223.0965 & 0.0055 \\
\hline & 213.0758 & 213.0677 & 0.0081 \\
\hline & 177.1053 & 177.0901 & 0.0152 \\
\hline & 151.0814 & 151.0754 & 0.0060 \\
\hline \multirow[t]{2}{*}{$\mathrm{H} 3[\mathrm{M}+\mathrm{H}]^{+}$} & 505.2482 & 505.2464 & 0.0018 \\
\hline & 262.1631 & 262.1438 & 0.0193 \\
\hline \multirow[t]{3}{*}{$\mathrm{N} 1[\mathrm{M}+\mathrm{H}]^{+}$} & 487.2875 & 487.2803 & -0.0072 \\
\hline & 280.1684 & 280.1543 & -0.0141 \\
\hline & 177.1003 & 177.0901 & -0.0102 \\
\hline $\mathrm{O} 1[\mathrm{M}+\mathrm{H}]^{+}$ & 294.1384 & 294.1580 & 0.0196 \\
\hline \multirow[t]{3}{*}{$\mathrm{O} \times 3[\mathrm{M}+\mathrm{H}]^{+}$} & 471.2718 & 471.2490 & -0.0228 \\
\hline & 248.1322 & 248.1281 & -0.0041 \\
\hline & 177.0951 & 177.0910 & -0.0041 \\
\hline \multirow[t]{2}{*}{$\mathrm{O} \times 4[\mathrm{M}+\mathrm{H}]^{+}$} & 293.2008 & 293.1860 & -0.0148 \\
\hline & 262.1570 & 262.1438 & -0.0132 \\
\hline \multirow[t]{3}{*}{$\mathrm{O} 5[\mathrm{M}+\mathrm{H}]^{+}$} & 485.2667 & 485.2646 & -0.0021 \\
\hline & 262.1502 & 262.1438 & -0.0064 \\
\hline & 177.0901 & 177.0910 & 0.0009 \\
\hline UV1 $[\mathrm{M}+\mathrm{H}]^{+}$ & 279.1682 & 279.1703 & 0.0021 \\
\hline \multirow[t]{2}{*}{ UV2 $[\mathrm{M}+\mathrm{H}]^{+}$} & 309.1932 & 309.1809 & -0.0123 \\
\hline & 278.1543 & 278.1387 & -0.0156 \\
\hline \multirow[t]{3}{*}{ UV3 $[\mathrm{M}+\mathrm{H}]^{+}$} & 485.2814 & 485.2646 & -0.0168 \\
\hline & 278.1543 & 278.1387 & -0.0156 \\
\hline & 177.1003 & 177.0901 & -0.0102 \\
\hline \multirow[t]{4}{*}{ UV4 $[\mathrm{M}+\mathrm{H}]^{+}$} & 455.2592 & 455.2540 & -0.0052 \\
\hline & 262.1570 & 262.1438 & -0.0132 \\
\hline & 177.1003 & 177.0901 & -0.0102 \\
\hline & 151.0860 & 151.0754 & -0.0106 \\
\hline
\end{tabular}

unidentified peak. Separation of the basic hydrolysis degradation products of ivabradine was achieved with satisfactory result (Figure 2B).

Complete degradation of IVA was observed in all samples containing hydrogen peroxide (Figures 3A-C). Chromatographic separation of degradation products was achieved. It was noted, that peaks corresponding to the products Ox5 and $\mathbf{O x} 4$ are smaller in case the higher concentration of hydrogen peroxide is used in respective samples.

During $24 \mathrm{~h}$ photodegradation of IVA, six degradation products were produced (Figure 4A). 48-h exposure to UV radiation caused complete decomposition of IVA in solution
(Figure 4B) as well as reduction of the intense of peak corresponding to the product UV2. Peaks separation in each UV-tested samples were satisfactory. A lot of photoproducts in samples and relatively short time of analysis resulted in insufficient separation of compound UV1. Solid powder form of ivabradine, exposed to irradiation for $120 \mathrm{~h}$, was proved to be durable, because any degradation product on the chromatogram was reveled (Figure 4C).

Determination of degradation products is presented in Table 1. Differences in retention times and distorted shape of the peaks corresponding to ivabradine compound tested in hydrolytic as well as photolytic reaction, is probably caused by the formation of enantiomers during degradation processes.

\section{Degradation Product Identification}

Using the above described apparatus and conditions, MS/MS analyses were performed for all chromatographic peaks (Francois-Bouchard et al., 2000; Lu et al., 2012).

The resulting MS/MS spectra with the proposed fragmentation patterns are presented in Figures 5-11. The proposed structures of degradation products together with other experimental data are presented in Table 2. The accuracy of the experimental mass degradation products with the theoretical masses are shown in Table 3.

The ketone group on the benzoazepine ring in compound H1 has been oxidized to a carboxyl group (Figure 5). The characteristic peak $\mathrm{m} / \mathrm{z}=280$ on the mass spectrum corresponding to the open azepine ring near the nitrogen, is observed for three of the four products of hydrolysis (Figures 5, 6, and 8). Water and $\mathrm{HCl}$ near the benzocyclobutene in compounds $\mathrm{H} 1$ and $\mathrm{H} 2$ are attached without a covalent bond, a kind of adducts may be formed. The situation is similar for the product $\mathbf{H} 3$, except that here the ring benzoazepine is intact (no peak of $\mathrm{m} / \mathrm{z}=280$ ) and the fragmentation spectrum of MS/MS proved there is impossible sufficiently formation of the $\mathrm{HCl}$ adduct closely to the molecule (Figure 7). Compound N1, as another product of ivabradine hydrolysis (Figure 8) differs only by oxidized carboxyl group on the benzoazepine ring near the nitrogen, what is observed as opening of the ring.

Due to the high level of noise and discrepancies in the resulting MS/MS spectrum of compound $\mathbf{O x} 2$, its identification is impossible, but due to repetition of its occurrence, there is importance to place attention on that compound in stability testing of ivabradine.

Limitations of the MS-Q-TOF method used for identification of degradation products of IVA did not allow for a clear determination of the attachment site of the hydroxyl group in compound $\mathbf{O x} 3$, but it is possible the covalent bond forms between nitrogen atoms in the molecule.

Compounds Ox4 and Ox1 have similar masses (m/z 293.20 and 294.1388, respectively) as well as the fragmentation spectra. Differences are in the presence of diverse substituents near the nitrogen atom in the molecule chain, a methyl group in $\mathbf{O x} 4$ (Figure 9), and oxygen in Ox1. Oxygen is coupled to the nitrogen atom also in case of compound $\mathbf{O x} 5$, where it forms $\mathrm{N}$-oxide bond. 
TABLE 4 | ADME/Tox calculations for ivabradine and selected degradation products.

\begin{tabular}{|c|c|c|c|c|c|c|c|}
\hline & & & [19] & [18] & [18] & [18] & [18] \\
\hline No. & {$[\mathrm{M}+\mathrm{H}]^{+}$} & SMILES & $\begin{array}{c}\text { HCN4 } \\
\text { inhibitiona }^{a}\end{array}$ & $\begin{array}{c}\text { CYP2D6 } \\
\text { inhibition }\end{array}$ & $\begin{array}{c}\text { CYP3A4 } \\
\text { inhibition }\end{array}$ & $\log \mathrm{P}_{\mathrm{o} / \mathrm{w}}$ & $\begin{array}{l}\text { Aqueous } \\
\text { solubility }\end{array}$ \\
\hline IVA & 468 & $\begin{array}{l}\mathrm{CN}(\mathrm{CCCN} 1 \mathrm{CCc} 2 \mathrm{cc} \\
(\mathrm{c}(\mathrm{cc} 2 \mathrm{CC} 1=\mathrm{O}) \mathrm{OC}) \mathrm{OC}) \\
\mathrm{CC} 3 \mathrm{Cc} 4 \mathrm{c} 3 \mathrm{cc}(\mathrm{c} \\
(\mathrm{c} 4) \mathrm{OC}) \mathrm{OC}\end{array}$ & $0.96^{b}$ & $\begin{array}{l}\text { Inhibitor } \\
\left(57.0 \%{ }^{\mathrm{C}}\right)\end{array}$ & $\begin{array}{l}\text { Inhibitor } \\
\left(74.0 \%{ }^{\mathrm{C}}\right)\end{array}$ & $\begin{array}{c}3.18 \log \\
\text { unit } \pm 0.38^{d}\end{array}$ & $\begin{array}{c}3.51- \\
\log (\mathrm{mol} / \mathrm{L}) \pm 0.70^{d}\end{array}$ \\
\hline N1 & 487 & $\begin{array}{l}\mathrm{CN}(\mathrm{CCCNCC} 1 \mathrm{cc} \\
(\mathrm{c}(\mathrm{cc} 1 \mathrm{CC}(=\mathrm{O}) \mathrm{O}) \\
\text { OC)OC)CC2Cc3c2cc } \\
\text { (c(c3)OC)OC }\end{array}$ & $0.28^{b}$ & $\begin{array}{c}\text { Non-inhibitor } \\
\left(65.0 \%{ }^{\mathrm{c}}\right)\end{array}$ & $\begin{array}{c}\text { Non-inhibitor } \\
\left(84.0 \%{ }^{\mathrm{c}}\right)\end{array}$ & $\begin{array}{c}2.71 \log \\
\text { unit } \pm 0.38^{d}\end{array}$ & $\begin{array}{c}2.39- \\
\log (\mathrm{mol} / \mathrm{L}) \pm 0.70^{d}\end{array}$ \\
\hline Ox1 & 294 & $\begin{array}{l}\mathrm{COc} 1 \mathrm{cc} 2 \mathrm{c}(\mathrm{cc} 1 \mathrm{OC}) \\
\mathrm{CC}(=\mathrm{O}) \mathrm{N}(\mathrm{CC} 2) \\
\mathrm{CCCN}[\mathrm{O}-]\end{array}$ & $0.40^{b}$ & $\begin{array}{c}\text { Non-inhibitor } \\
\left(84.0 \%{ }^{c}\right)\end{array}$ & $\begin{array}{c}\text { Non-inhibitor } \\
\left(86.0 \%{ }^{\mathrm{C}}\right)\end{array}$ & $\begin{array}{c}0.57 \log \\
\text { unit } \pm 0.74^{d}\end{array}$ & $\begin{array}{c}0.98- \\
\log (\mathrm{mol} / \mathrm{L}) \pm 0.70^{d}\end{array}$ \\
\hline Ox4 & 293 & $\begin{array}{l}\text { CNCCCN1CCc } \\
2 \mathrm{cc}(\mathrm{c}(\mathrm{cc} 2 \mathrm{CC} 1=\mathrm{O} \\
) \mathrm{OC}) \mathrm{OC}\end{array}$ & $0.82^{b}$ & $\begin{array}{c}\text { Non-inhibitor } \\
\left(69.0 \%{ }^{c}\right)\end{array}$ & $\begin{array}{c}\text { Non-inhibitor } \\
\left(89.0 \%{ }^{c}\right)\end{array}$ & $\begin{array}{c}1.23 \log \\
\text { unit } \pm 0.38^{d}\end{array}$ & $\begin{array}{c}1.36- \\
\log (\mathrm{mol} / \mathrm{L}) \pm 0.70^{d}\end{array}$ \\
\hline Ox5 & 485 & $\begin{array}{l}\mathrm{C}[\mathrm{N}+](\mathrm{CCCN} 1 \mathrm{CC} \\
\mathrm{c} 2 \mathrm{cc}(\mathrm{c}(\mathrm{cc} 2 \mathrm{CC} 1=\mathrm{O}) \\
\mathrm{OC}) \mathrm{OC})(\mathrm{CC} 3 \mathrm{Cc} 4 \mathrm{c} 3 \mathrm{cc} \\
(\mathrm{c}(\mathrm{c} 4) \mathrm{OC}) \mathrm{OC})[\mathrm{O}-]\end{array}$ & $0.77^{b}$ & $\begin{array}{c}\text { Non-inhibitor } \\
\left(79.0 \%{ }^{c}\right)\end{array}$ & $\begin{array}{l}\text { Inhibitor } \\
\left(62.0 \%{ }^{\mathrm{C}}\right)\end{array}$ & $\begin{array}{c}1.26 \log \\
\text { unit } \pm 0.74^{d}\end{array}$ & $\begin{array}{c}2.39- \\
\log (\mathrm{mol} / \mathrm{L}) \pm 0.70^{d}\end{array}$ \\
\hline UV1 & 279 & $\begin{array}{l}\mathrm{COc} 1 \mathrm{cc} 2 \mathrm{c} \\
(\mathrm{cc} 1 \mathrm{OC}) \mathrm{CC}(=\mathrm{O}) \\
\mathrm{N}(\mathrm{CC} 2) \mathrm{CCCN}\end{array}$ & $0.79^{b}$ & $\begin{array}{c}\text { Non-inhibitor } \\
\left(85.0 \%{ }^{\mathrm{C}}\right)\end{array}$ & $\begin{array}{c}\text { Non-inhibitor } \\
\left(87.0 \%{ }^{\mathrm{C}}\right)\end{array}$ & $\begin{array}{c}0.42 \log \\
\text { unit } \pm 0.38^{d}\end{array}$ & $\begin{array}{c}0.9- \\
\log (\mathrm{mol} / \mathrm{L}) \pm 0.70^{d}\end{array}$ \\
\hline UV4 & 455 & $\begin{array}{l}\mathrm{COc} 1 \mathrm{cc} 2 \mathrm{c}(\mathrm{cc} 1 \mathrm{OC}) \\
\mathrm{CC}(=\mathrm{O}) \mathrm{N}(\mathrm{CC} 2) \\
\mathrm{CCCNCC3Cc4c3cc} \\
(\mathrm{c}(\mathrm{c} 4) \mathrm{OC}) \mathrm{OC}\end{array}$ & $0.94^{b}$ & $\begin{array}{c}\text { Non-inhibitor } \\
\left(59.0 \%{ }^{\mathrm{C}}\right)\end{array}$ & $\begin{array}{l}\text { Inhibitor } \\
\left(76.0 \%{ }^{\mathrm{C}}\right)\end{array}$ & $\begin{array}{c}2.43 \mathrm{Log} \\
\text { unit } \pm 0.38^{d}\end{array}$ & $\begin{array}{c}3.03- \\
\log (\mathrm{mol} / \mathrm{L}) \pm 0.70^{d}\end{array}$ \\
\hline
\end{tabular}

a Potassium/sodium hyperpolarization-activated cyclic nucleotide-gated channel 4; ${ }^{b}$ probability; ${ }^{c}$ accuracy; ${ }^{d}$ within a confidence interval of $66 \%$.

Compound UV1 (Figure 10) is the degradation product of the smallest identified molecular weight identified of IVA $(\mathrm{m} / \mathrm{z}=279.1725)$. For compounds UV2 and UV3 it is impossible to predict its structures, but the data suggest that $\mathrm{OH}$ group is joined in the region of benzoazepine ring. Compound UV4 is varies from ivabradine by the lack of the methyl group on the nitrogen atom (Figure 11). It is proved, that compound UV4 is a metabolite of ivabradine produced by cytochrome P450.

\section{ADME/Tox Screening for Degradation Products}

The calculation of pharmacological and toxicological properties could be done only for six ivabradine degradation products, since its chemical structures managed to establish for obtained data. In other degradation products we proposed the most probable chemical structures only on the basis of MS/MS analysis.

The pharmacological effect of ivabradine is associated with blocking of HCN4 channels (Postea and Biel, 2011). Therefore, in order to make comparative analysis calculations were also done for ivabradine, even though the drug is introduced into clinical practice. The in silico calculations made for ivabradine and selected degradation products demonstrated high probability of HCN4 channel inhibition for Ox4, Ox5, UV1, and UV4, which may indicate a certain pharmacological action of these products (Table 4). For a compound UV4 calculated value of inhibition is very high (0.94) and only slightly lower than calculated value for the ivabradine (0.96). It is known that compound UV4 is a metabolite of ivabradine with proved ability to inhibit HCN4 channels. Other studies have shown that it is much weaker inhibitor than ivabradine (DiFrancesco, 2010).

Ivabradine and its degradation products showed no mutagenicity in the Ames test. It was also shown, that no inhibition of cytochromes: CYP2C9, CYP2C19, and CYP1A2 (data calculated but not included in Table 4) occurs for all products of degradation and ivabradine itself. According to obtained calculations only ivabradine inhibits CYP2D6. Some authors refer only to the inhibition of CYP3A4 by IVA (DiFrancesco, 2010; Postea and Biel, 2011), which is confirmed by our calculations. Compound UV4, which has lower pharmacological activity than ivabradine, demonstrated inhibition of cytochrome, the same as compound Ox5.

The values of $\log \mathrm{P}$ and aqueous solubility, allow to divide identified degradation products into three groups. Degradation products of ivabradine - compounds UV4 and N1 have slightly reduced values of $\log \mathrm{P}$ and solubility in comparison to IVA. In the case of degradation products Ox4 and Ox5, significant reduction of lipophilicity is observed. A strong decrease in lipophilicity and aqueous solubility occurred in the case of compounds Ox1 and UV1. Significant reduction of the log $P$ values can be explained by an aromatic ring being highly lipophilic moiety. 


\section{CONCLUSION}

Stress testing of ivabradine was presented with successful identification and characterization of its degradation products. The obtained compounds showed no mutagenic effects in performed in silico models, in which toxicity and the effect on cytochromes seems to be small. Another important aspect was, that their lower water solubility and lipophilicity in comparison to ivabradine, may influence their bioavailability after oral administration. Above all, lower pharmacological activity of degradation products was proven in calculated value of channel inhibition HCN4. There was also computationally confirmed pharmacological activity of compound UV4.

\section{REFERENCES}

Alavijeh, M. S., Chishty, M., Qaiser, M. Z., and Palmer, A. M. (2005). Drug metabolism and pharmacokinetics, the blood-brain barrier, and central nervous system. NeuroRx 2, 554-571. doi: 10.1602/neurorx.2.4.554

Bergström, C. A. (2005). In silico predictions of drug solubility and permeability: two rate-limiting barriers to oral drug absorption. Basic Clin. Pharmacol. Toxicol. 96, 156-161. doi: 10.1111/j.1742-7843.2005.pto96 0303.x

Carstensen, J. T., and Rhodes, C. H. (eds). (2000). Drug Stability: Principles and Practices, 3rd Edn. New York, NY: Marcel Dekker.

Danielson, P. B. (2002). The cytochrome P450 superfamily: biochemistry, evolution and drug metabolism in humans. Curr. Drug Metab. 3, 561-597. doi: $10.2174 / 1389200023337054$

DiFrancesco, D. (2010). The role of the funny current in pacemaker activity. Cir. Res. 106, 434-446. doi: 10.1161/CIRCRESAHA.109.20804

Dow, L. K., Hansen, M. M., Pack, B. W., Page, T. J., and Baertschi, S. W. (2013). The assessment of impurities for genotoxic potential and subsequent control in drug substance and drug product. J. Pharm. Sci. 102, 1404-1418. doi: $10.1002 /$ jps. 23462

EMA (2015). Available at: http://www.ema.europa.eu/docs/en_GB/document _library/EPAR_-_Scientific_Discussion/human/000597/WC500043587.pdf [Accessed 17 August, 2015].

EMEA (2004). Committee for Medicinal Products for Human Use (CHMP), Guideline on the limits of genotoxic impurities, CPMP/SWP/5199/02, London.

ePhysChem. (2015). Available at: http://www.eadmet.com/en/physprop.php [Accessed 17 August, 2015].

Francois-Bouchard, M., Simonin, G., Bossant, M.-J., and Boursier-Neyret, C. (2000). Simultaneous determination of ivabradine and its metabolites in human plasma by liquid chromatography-tandem mass spectrometry. J. Chromatogr. B 745, 261-269. doi: 10.1016/S0378-4347(00)00275-279

Gfeller, D., Grosdidier, A., Wirth, M., Daina, A., Michielin, O., and Zoete, V. (2014). SwissTargetPrediction: a webserver for target prediction of bioactive small molecules. Nucleic Acids Res. 42, W32-W38.

Glass, B. D., Novák, C., and Brown, M. E. (2004). The thermal and photostability of solid pharmaceuticals. J. Therm. Anal. Calorim. 77, 1013-1036. doi: 10.1016/j.jpba.2015.01.012

Huynh-Ba, K. (ed.). (2008). "Handbook of stability testing," in Pharmaceutical Development: Regulations, Methodologies, and Best Practices, (New York, NY: Springer Science \& Business Media).

ICH Q1A (R) (1993). Stability Testing of New Drug Substances and Products. Geneve: International Conference on Harmonization.

ICH Q1A (R2) (2003). Stability Testing of New Drug Substances and Products. Geneve: International Conference on Harmonization.

ICH Q3A (1993). "Impurities in new drug substances," in Proceeding of the Tripartite International Conference on Harmonization Guideline, Geneve.

ICH Q3B (R) (2000). Draft revised guidance on impurities in new drug products. Federal Register 65, 44791-44797.

Jamrógiewicz, M. (2016). Consequences of new approach of chemical stability tests of active pharmaceutical ingredients (APIs). Front. Pharmacol. 7:17. doi: $10.3389 /$ fphar.2016.00017

\section{AUTHOR CONTRIBUTIONS}

PP: co-operation in the development of research area and methodology; co-operation in the collecting the literature; coordination in the manuscript preparation; co-operation in MS/MS spectra analysis; Toxtree analysis; MJ: cooperation in the manuscript preparation; co-operation in MS/MS spectra analysis; co-operation in the collecting the literature; corresponding author; JN: co-operation in the development of research area and methodology; WHB: LC-MS/MS method development; LC-MS/MS spectra recording; KC: Toxtree analysis; co-operation in the manuscript preparation.

Lu, C., Jia, Y., Yang, J., Jin, X., Song, Y., Liu, W., et al. (2012). Simultaneous determination of ivabradine and $\mathrm{N}$-desmethyl ivabradine human plasma and urine using a LC-MS/MS method: application to a pharmacokinetic study. Acta Pharmaceut. Sin. B 2, 205-212. doi: 10.1016/j.apsb.2012.01.004

Maggio, R. M., Vignaduzzo, S. E., and Kaufman, T. S. (2013). Practical and regulatory considerations for stability-indicating methods for the assay of bulk drugs and drug formulations. TrAC-Trends Anal. Chem. 49, 57-70. doi: 10.1016/j.trac.2013.05.008

Modi, S., Hughes, M., Garrow, A., and White, A. (2012). The value of in silicochemistry in the safety assessment of chemicals in the consumer goods and pharmaceutical industries. Drug Discov. Today 17, 135-142. doi: 10.1016/j.drudis.2011.10.022

Olsen, B. A., and Larew, L. A. (2005). "Comparative stress stability studies for rapid evaluation of manufacturing changes or materials from multiple sources," in Pharmaceutical Stress Testing: Predicting Drug Degradation, ed. S. W. Baertschi (London: Informa Healthcare), 235-259.

Patel, P. N., Borkar, R. M., Kalariya, P. D., Gangwal, R. P., Sangamwar, A. T., Samanthula, G., et al. (2015). Characterization of degradation products of Ivabradine by LC-HR-MS/MS: a typical case of exhibition of different degradation behaviour in $\mathrm{HCl}$ and $\mathrm{H} 2 \mathrm{SO} 4$ acid hydrolysis. J. Mass Spectrom. 50, 344-353. doi: 10.1002/jms.3533

Postea, O., and Biel, M. (2011). Exploring HCN channels as novel drug targets. Nat. Rev. Drug Discov. 10, 903-914. doi: 10.1038/nrd3576

Singh, S., Handa, T., Narayanam, M., Sahu, A., Junwal, M., and Shah, R. P. (2012). A critical review on the use of modern sophisticated hyphenated tools in the characterization of impurities and degradation products. J. Pharmaceut. Biomed. Anal. 69, 148-173. doi: 10.1016/j.jpba.2012.03.044

Singh, S., Junwal, M., and Modhe, G. (2013). Forced degradation studies to assess the stability of drugs and products. TrAC-Trends Anal. Chem. 49, 71-88. doi: 10.1016/j.jpba.2009.06.046

Toxtree. (2015). Estimation of Toxic Hazard - A Decision Tree Approach v. 2.6.6 Available at: http://toxtree.sourceforge.net [Accessed 17 August, 2015].

Waterman, K. C., and Adami, R. C. (2005). Accelerated aging: prediction of chemical stability of pharmaceuticals. Int. J. Pharm. 293, 101-125. doi: 10.1016/j.ijpharm.2004.12.013

Zanger, U. M., and Schwab, M. (2013). Cytochrome P450 enzymes in drug metabolism: regulation of gene expression, enzyme activities, and impact of genetic variation. Pharmacol. Therapeut. 138, 103-141. doi: 10.1016/j.pharmthera.2012.12.007

Conflict of Interest Statement: The authors declare that the research was conducted in the absence of any commercial or financial relationships that could be construed as a potential conflict of interest.

Copyright (c) 2016 Pikul, Jamrógiewicz, Nowakowska, Hewelt-Belka and Ciura. This is an open-access article distributed under the terms of the Creative Commons Attribution License (CC BY). The use, distribution or reproduction in other forums is permitted, provided the original author(s) or licensor are credited and that the original publication in this journal is cited, in accordance with accepted academic practice. No use, distribution or reproduction is permitted which does not comply with these terms. 